\title{
Project Work Based Modules Development on Construction and Building Utilities Subjects to Increase Student Learning Outcomes of Vocational High School
}

\author{
Enggar Fiolentin ${ }^{1, a^{*}}$, Kusnan ${ }^{2 b}$, Suparji2 ${ }^{2 c}$ and Tri Rijanto ${ }^{2 d}$ \\ 1Technology and Vocational Education Program, Postgraduate at State University of Surabaya, Surabaya, 60213, \\ Indonesia \\ 2Technology and Vocational Education Program, Postgraduate at State University of Surabaya, Surabaya, 60213, \\ Indonesia \\ a enggarfiolentin16070895008@mhs.unesa.ac.id; b kusnan@unesa.ac.id; c suparji@unesa.ac.id; \\ dtririjanto@unesa.ac.id \\ *Corresponding Author : enggarfiolentin16070895008@mhs.unesa.ac.id |Phone Number: 082257815722
}

\begin{abstract}
This study aims to develop a Work-Based Modules project in Construction and Building Utilities subjects to increase student learning outcomes of State Vocational High School 1 Sidoarjo. And to analyze the feasibility of the module in terms of (1) validity; (2) practicality; (3) has a project work-based Modules; (4) student learning outcomes after being taught by project-based Modules. This development research was carried out based on the six stages of the development method. The instruments used in this study were: (1) Questionnaire. Syllabus, lesson plans, Student Worksheets (SW) \& Assessment instruments to measure the validity of values; (2) Learning management observation sheet, observation sheet to measure practicality; (3) learning outcomes test to measure the effectiveness of learning devices. The research was conducted on class XI students with competency skills in Modeling Design and Building Information. The results showed that the project-based Modules that works on the subjects of Construction and Building Utilities developed is valid in terms of validity, Practical interms of practicality, and proven effective in terms of effectiveness. Mean while, the learning outcomes indicated that (1) the Cognitive learning outcomes of students whose learning using project-based Modules and SW were significantly higher than students using only SW; (2) the learning outcomes in the Affective domain for students whose learning uses project-based modules, is significantly higher than students who learn only using SW; and (3) the learning outcomes inthe Psychomotor domain of students whose learning uses project-based Modules are significantly higher than those of students who only using SW.
\end{abstract}

Keywords: project work; modules; research \& development; construction and building utilities; learning outcomes

\section{Introduction}

Education is a conscious and planned effort to create an atmosphere of learning and the learning process so that students are able to develop their potential. This is as written in Law Number 20 of 2005 concerning the National Education System, which states that the national education system must be able to ensure equitable educational opportunities, increase the quality and relevance, and efficiency of education management to face challenges in accordance with the demands of changing local life, national, and global. Vocational High School (VHS)/Sekolah Menengah Kejuruan (SMK) is a vocational education for the upper secondary level provided by the government in order to prepare a ready-made work force. The government has made efforts to increase the quality of education and of Vocational High School graduates by implementing the 2013 curriculum revised 2018 in learning. With the implementation of the 2013 curriculum, vocational students are expected to be able to take advantage of this learning to help them learn to think more critically and learn how to behave and solve problems in real situations (Sastrikirana, 2015). In addition, the quality of Vocational High School graduates can be said to be good if the learning process goes well.

Based on the results of interviews with teachers on preliminary observations, students consider that the Construction and Building Utilities subject is a difficult subject, especially in the material of Drawing Stair Construction. This can be seen from the student learning outcomes that are still below the Minimum Completeness Criteria (MCC)/Kreteria Ketuntasan Minimal (KKM) with a value percentage of $\geq 75 \%$. In addition, information was obtained that the learning process is often carried out conventionally, namely by 
the lecture method, which causes students to be less active during learning. Thus, teachers need to find the right solution to increase student scores on Building Construction and Utilities that are still below these minimum completeness standards. One of the efforts that can be done is by presenting a problem to be solved by students.

The learning model that can train students to develop problem-solving skills is project work. Project work or better known as project-based learning is an instructional approach that contextualizes learning by giving students problems to solve or products to develop (Garza, 2016: 142). Meanwhile, according to Muryanti (2015: 96), project work can provide many benefits when applied in learning, including promoting input and output that can be understood by students to gain successful experiences with the real world, and also support student centering during the learning process. In addition, another advantage of project work is that it can increase student motivation, improve their problem-solving skills, collaboration, and skills in managing resources (Khoirunisa et al., 2020). In the project work model, the problems given are related to real problems. So that this learning model is suitable for application to material related to everyday life, such as in Construction and Building Utilities subjects.

In addition, one alternative strategy to improve the quality of the learning process in schools can be done through the development of learning tools (Widyaningrum et al., 2013). The development of learning tools today is an urgent need because the implementation of the 2013 curriculum mandates teachers to develop student-centered learning (Rajabi et al., 2015). One of the learning tools that can be developed is a Modules. Modules are teaching packages in stages from certain subjects, where students study material from one unit to another (Hamalik, 2013: 145). Therefore, it is necessary to develop project work-based modules that will support student learning and are designed so that students are able to solve real problems. The developmentof learning tools for Construction and Building Utilities subjects in the form of project workbased Modules will be carried out on the topic of Drawing Staircase Construction. Drawing Staircase Construction was chosen as the teaching material because the basic competencies of staircase construction emphasize that students are able to apply technical specifications and conditions to the construction of wooden, concrete, and steel staircase drawings. So it is hoped that through the development of this Modules will be able to realize the achievement of these basic competencies.

\section{Literature Review}

\subsection{Project Work}

Project work is a learning model that provides the opportunity for teachers to manage learning in the classroom by involving a form of work that contains complex tasks based on very challenging questions and problems, thereby leading students to design, solve problems, make decisions, carry out investigative activities. , as well as giving students the opportunity to work independently (Nurhayati \& Harianti, 2015).

\subsection{Modules}

Modules can be viewed as a package of teaching programs consisting of components containing learning objectives, teaching materials, learning methods, tools or media, as well as learning resources and evaluation systems (Sudjana \& Rivai, 2002: 132).

\subsection{Validation}

A good (valid) learning tool is needed by every teacher, the learning device should be used if it has been declared valid by experts (Plomp \& Nieveen, 2013: 29).

\subsection{Practicality}

Learning tools are called practical if they are realistic and can be used with the learning device settings that have been designed and developed (Plomp \& Nieveen, 2013: 29).

\subsection{Effectiveness}

Plomp \& Nieveen (2013: 29) reveal that effectiveness is related to the use of learning tools that can produce the expected learning achievement. In other words, effectiveness shows the achievement of results, which in this case is student learning outcomes after participating in learning.

\subsection{Learning Outcomes}

Learning outcomes are abilities obtained by students after receiving learning, and are used to determine the extent to which teaching and learning actions or activities can achieve instructional goals achieved or mastered by students (Sudjana, 2011: 2).

\section{Research Method}

This study uses the Research and Development (R\&D) method which consists of 8 stages, namely: (1) potential and problems; (2) data collection; (3) product design; (4) design validation; (5) design 
improvements; (6) product testing; (7) product revision; and (8) testing the use of Sugiyono (2013: 407).

\subsection{Potentials and Problems}

Before the implementation of research and development, the researcher first conducts a preliminary study in the form of observations to collect preliminary information. This is done to identify and explore the need for learning media for students. The first time this was done by researchers to identify and explore needs, namely by distributing questionnaires to students, interviews with teachers in Construction and Building Utilities subjects, and examining modules and worksheets used by the school.

\subsection{Data Collection}

After filling out the questionnaire by students who had been determined by the researcher, namely 36 students of State Vocational High School 1 Sidoarjo - East Java, the information needed by the researcher to identify the ability to draw ladder construction and the student's needs for student teaching materials was obtained. The table shows the average score from filling out the questionnaire by students in Table 1.

Table 1. Students' Initial Experience in Drawing Staircase Construction

\begin{tabular}{clc}
\hline No & \multicolumn{1}{c}{ Statement } & Percentage of Answers "Yes" \\
\hline 1 & I've drawn stair construction & $29 \%$ \\
2 & I like to draw stair constructions & $12 \%$ \\
3 & Saya belajar menggambar kontruksi gambar dari media Modul dan LKS & $78 \%$ \\
4 & I learned to draw construction images from the Modules and LKS media & $85 \%$ \\
5 & I draw construction because of the teacher's assignment & $24 \%$ \\
6 & I can easily understand the contents of the worksheets & $20 \%$ \\
7 & I can study independently based on instructions in the module & $22 \%$ \\
8 & I can study independently based on instructions in the LKS & $25 \%$ \\
9 & I have trouble drawing staircase construction & $88 \%$ \\
& & $75 \%$ \\
\hline
\end{tabular}

Note: students stated that $75 \%$ of the scores

Based on Table 1 above, students stated that $75 \%$ of the scores were unsatisfactory, this was because there were still many students who could not understand the content of the material in the modules used by $24 \%$. Based on the table above, research is needed for the development of project work-based Modules on Construction and Building Utilities subjects that can improve student learning outcomes.

\subsection{Product Design}

At the product design stage, the design of teaching materials in the form of project work-based Modules currently implemented in Indonesia:

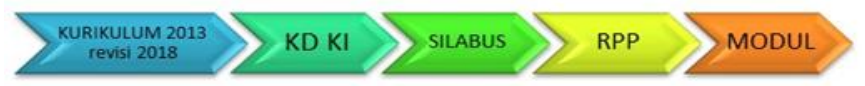

\subsection{Design Validation}

Figure 1. Product design

The validation of learning tools was carried out by experts or experts consisting of two Unesa lecturers and a teacher of State Vocational High School 1 Sidoarjo-East Java. The validation of learning tools includes the syllabus, lesson plans, worksheets, and assessment sheets from the three Cognitive, Affective and Psychomotor domains. The results of the validation of learning devices are shown in Table 2.

Table 2. Module Results

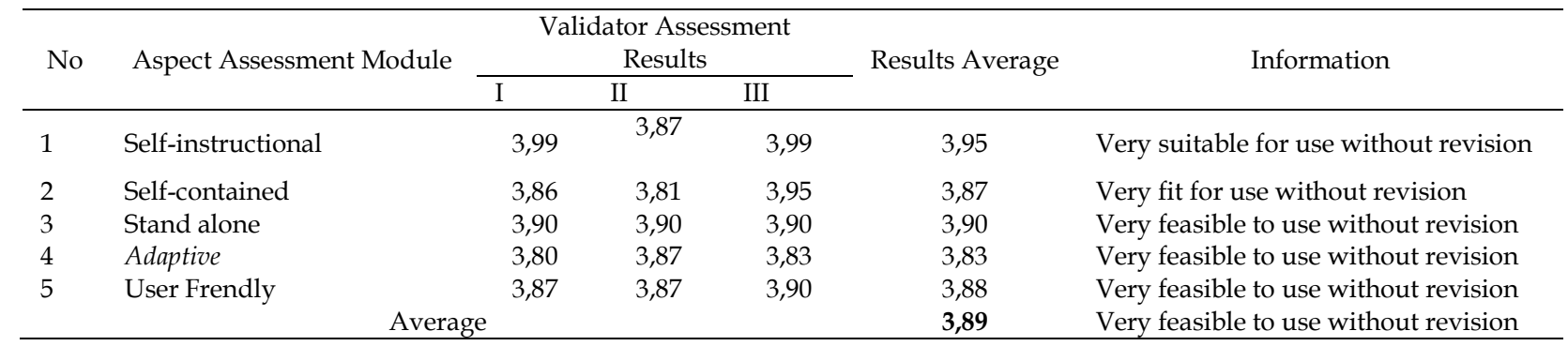




\subsection{Design improvements}

Design improvements are made to add to the layout or position of the module in the program unit which is described in diagrammatic form. Making the module map is compiled referring to the competency achievement diagram contained in the curriculum.

\subsection{Product Trial}

Analysis of multiple choice items was carried out after the questions were tested in the trial class totaling 36 students, after that they were analyzed to determine the quality of the questions before the questions were used in the writing data collection. There are 30 multiple choice questions as a writing instrument which were tested. The question is said to be valid because it has a significance value of less than 0.05 . The items were analyzed using the SPSS 20 software program and using ANATES V4. The validity of the items is shown in Table 3.

Table 3. Results of Question Item Validity using SPSS

\begin{tabular}{|c|c|c|c|c|c|}
\hline 1 & 0,000 & Valid & 16 & 0,000 & Valid \\
\hline 2 & 0,001 & Valid & 17 & 0,000 & Valid \\
\hline 3 & 0,001 & Valid & 18 & 0,000 & Valid \\
\hline 4 & 0,010 & Valid & 19 & 0,000 & Valid \\
\hline 5 & 0,000 & Valid & 20 & 0,000 & Valid \\
\hline 6 & 0,003 & Valid & 21 & 0,004 & Valid \\
\hline 7 & 0,005 & Valid & 22 & 0,000 & Valid \\
\hline 8 & 0,000 & Valid & 23 & 0,000 & Valid \\
\hline 9 & 0,008 & Valid & 24 & 0,000 & Valid \\
\hline 10 & 0,006 & Valid & 25 & 0,004 & Valid \\
\hline 11 & 0,000 & Valid & 26 & 0,002 & Valid \\
\hline 12 & 0,000 & Valid & 27 & 0,002 & Valid \\
\hline 13 & 0,000 & Valid & 28 & 0,001 & Valid \\
\hline 14 & 0,000 & Valid & 29 & 0,000 & Valid \\
\hline 15 & 0,000 & Valid & 30 & 0,000 & Valid \\
\hline
\end{tabular}

Note: The question is said to be valid because it has a significance value of less than 0.05

\subsection{Product Revisions}

The module based on project work on Construction and Building Utilities subjects has gone through the validation stage by experts before being tested. Based on the results of validation by experts, there are several parts of the modules that must be improved. Revisions made according to the suggestions of experts are as follows: (1) In the modules, the term "meeting" is replaced with "activity"; (2) Competence in the subject needs to be described; (3) The modules should include the observer, reviewer or modules editor; (4) The modules is equipped with a modules position map; (5) Modules writing techniques need to be improved; (6) The modules must contain learning project work.

\subsection{Trial Use}

The results of the practicality of project work-based modules in the Building Construction and Utilities subjects can be seen in Table 4 belows.

Table 4. Results of Project-Based Module Practicality

\begin{tabular}{clcc}
\hline No & \multicolumn{1}{c}{ Indicator } & Percentage \\
\hline 1 & Learning Implementation Observation Data & & \\
2 & Data Readability of Modules and Student Worksheet (SW) / Lembar Kerja Siswa (LKS) by students & $83 \%$ \\
3 & Student Activity Data & Average & $82,4 \%$ \\
& & $81,33 \%$ & $\mathbf{8 3} \%$ \\
\hline
\end{tabular}

Note: Average Results of Project-Based Module Practicality

The results of the effectiveness of project work-based modules on Construction and Building Utilities subjects are obtained by determining student learning completeness, both individual completeness and classical completeness in Table 5. 
Table 5. Completeness of Student Learning Outcomes

\begin{tabular}{clccc}
\hline No & \multicolumn{1}{c}{ Instrumen } & Average & $\begin{array}{c}\text { Classical Completeness of } \\
\text { Learning Outcomes }\end{array}$ & Category \\
\hline 1 & Cognitive Learning Outcomes Test & 83,17 & $100 \%$ & Finish Learning \\
2 & Afective Learning Outcomes Test & 82,32 & $100 \%$ & Finish Learning \\
3 & Psychomotor Learning Outcomes Test & 84,33 & $100 \%$ & Finish Learning \\
\hline
\end{tabular}

\section{Research Results}

\subsection{The Validity of Project Work-Based Modules in Construction and Building Utilities Subjects}

Project work-based Modules validation in Construction and Building Utilities subjects was carried out by three experts, namely two of State Surabaya University lecturers majoring in Civil Engineering and a teacher of the Building Modeling and Information Design Expertise Program of State Vocational High School 1 Sidoarjo - East Java. Based on the results of the validation of all experts, it shows that the Modules is very suitable for use without revision with an average score of 3.89. In addition, the results of the validation of the learning tools as a whole were obtained with details of the acquisition of a Syllabus score of 3.90, Lesson Plan (LP)/RPP (Rencana Pelaksanaan Pembelajaran) of 2.75, Modules of 3.89, Student Worksheet (SW)/Lembar Kerja Siswa (LKS) of 3.32. While the Cognitive domain assessment sheet obtained a score of 3.32, the Affective domain of 3.50 and the Psychomotor domain of 3.50. So, these results average that the learning device is suitable for learning.

\subsection{Practicality of Project Work-Based Modules in Construction and Building Utilities Subjects}

Based on the practicality analysis of project work-based modules on the subject of Construction and Building Utilities, the practicality test results were obtained from the observation of learning implementation by $83 \%$, data on the readability of modules and worksheets of $82.4 \%$, and student activity of $81.33 \%$. Overall, the practicality of the project work-based module obtained an average score of $83 \%$. This result means that the practicality of project work-based modules is included in the very good criteria.

\subsection{Effectiveness of Project Work-Based Modules on Construction and Building Utilities Subjects}

Based on the results of the effectiveness of project work-based Modules on the Subject of Construction and Building Utilities, obtaining classical student learning completeness because $100 \%$ of students achieved a score of more than $75 \%$. In addition, the average completeness of learning outcomes in The Cognitive domain was $83.17 \%$, and average -Average mastery learning outcomes in The Affective domain of $82.32 \%$, while the average mastery of learning outcomes in the Pychomotor domain was $84.33 \%$. Thus, classical completeness can be said to be very good.

\subsection{Student Learning Outcomes After Teaching with Project Work-Based Modules in Construction and} Building Utilities Subjects.

\section{a. Cognitive Learning Outcomes}

Based on the results of the $t$ test on learning outcomes in the cognitive domain, the tcount was 23.026 and a significance value of 0.000 . This means that there are differences in cognitive learning outcomes between students taught with project work-based modules compared to students taught with conventional learning with Student Worksheet (SW)/Lembar Kerja Siswa (LKS).

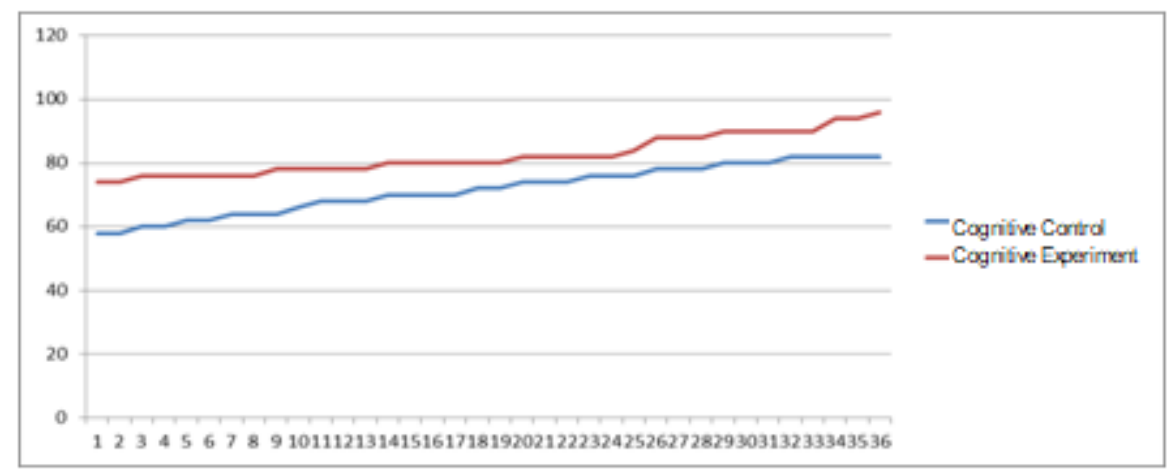

Figure 2. Comparison of cognitive learning outcomes between the experimental class and the control class 


\section{b. Affective Domain Learning Outcomes}

Based on the results of the $t$ test on learning outcomes in the affective domain, the tcount was 21.442 and a significance value of 0.000 . This means that there are differences in affective learning outcomes between students taught with project work-based modules compared to students taught with conventional learning with Student Worksheet (SW)/Lembar Kerja Siswa (LKS).

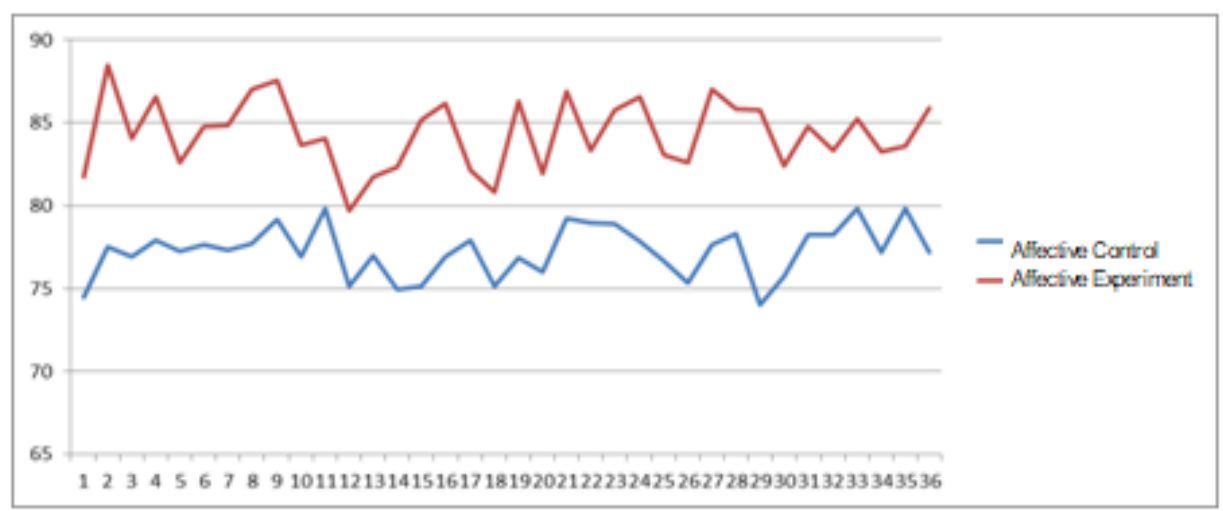

Figure 3. Comparison of affective learning outcomes between the experimental class and the control class

\section{c. Psychomotor Learning Outcomes}

Based on the results of the $t$ test on the learning outcomes of the psychomotor domain, the $t$ count was 9.178 and a significance value of 0.000 . This means that there are differences in Psychomotor learning outcomes between students taught with project work-based modules compared with students taught with conventional learning with Student Worksheet (SW) )/Lembar Kerja Siswa (LKS).



Figure 4. Comparison of psychomotor learning outcomes between the experimental class and the control class in

\section{Conclusion}

In terms of validity, the modules is based on project work in the Construction and Building Utilities subject developed proven, the modules is valid for learning. In terms of practicality, this project work-based modules on the subject of Building Construction and Utilities has proven to be practical for learning. In terms of effectiveness, the project work-based modules on the Building Construction and Utilities subject has been considered effective both from individual student learning completeness and classically. Students' Learning Outcomes in the cognitive, affective, psychomotor domains of students who learn using project work-based modules, are significantly higher than students who learn using Student Worksheet (SW).

\section{Recommendation}

Project work-based modules on Construction and Building Utilities subjects can be used as a learning medium in Construction and Building Utilities subjects to improve learning outcomes in vocational high schools. It is hoped that modules development can be applied to all subjects in vocational high schools, especially in subjects where practicum cannot be done to provide visualization to students. In the feasibility test or implementation of the developed modules, it should not be limited to just one school, but more expanded so that the quality of the module along with other learning tools will increase and can be used to assist teachers in implementing learning activities. For other researchers who are interested in conducting similar module development research, they should add other material. 


\section{References}

Garza, A. M. E. D. de la. (2016). Using project work in alternative assessment. In A guidebook for assessing learning (pp. 141-149). Mexico: Primera Edición

Hamalik, O. (2013). Proses belajar mengajar. Jakarta: Bumi Aksara.

Khoirunisa, A. Z., Sunarya, I. K., \& Rahdiyanta, D. (2020). Dampak implementasi model pembelajaran project-work berbasis karakter terhadap sikap dan prestasi belajar mahasiswa. Jurnal Dinamika Vokasional Teknik Mesin, 5(1), 57-68. Download form https://doi.org/10.21831/dinamika.v5i1.30996

Muryanti, V. (2015). Project-based assessment models for senior high school grade XI. Indonesian Journal of English Language Studies, 1(2), 183-206

Nurhayati, A. S., \& Harianti, D. (2015). Model pembelajaran project based learning (PjBL) (Vol. 151).

Plomp, T., \& Nieveen, N. (2013). An introduction to educational design research. Enschede: SLO-Netherlands Institute for Curriculum. Development. of operating system installation learning tools with project-based learning models. Indonesian Jurnal of Vocational Studies, UNESA, 3(01), 247005

Sastrikirana, A. (2015). An authentic project-based assessment model for vocational high school students Grade X. Indonesian Journal of English Language Studies, 1(2), 151-166. Retrieved from https://ejournal.usd. ac.id/index.php/IJELS

Sudjana, N., \& Rivai, A. (2002). Learning Media. Bandung: Sinar Baru Algesindo

Sudjana, N. (2011). Assessment of the results of the teaching and learning process. Bandung: PT Remaja Rosdakarya

Sugiyono. (2013). Metodologi penelitian kualitatif R\&D. Bandung: Alphabeta.

Undang-Undang Nomor 20 Tahun 2005 tentang Sistem Pendidikan Nasional (2005). Indonesia

Widyaningrum, R., Sarwanto, \& Karyanto, P. (2013). Pengembangan modul berorientasi poe (predict, observe, explain) berwawasan lingkungan pada materi pencemaran untuk meningkatkan hasil belajar siswa. BIOEDUKASI, 6(1), 1-18.

Purwanto, Rahadi, A., \& Lasmono, S. (2007). Pengembangan modul. Jakarta: Departemen Pendidikan Nasional Pusat Teknologi Informasi dan Komunikasi Pendidikan.

Rajabi, M., Ekohariadi, E., \& Buditjahjanto, I. (2015). Pengembangan perangkat pembelajaran instalasi sistem operasi dengan model pembelajaran berbasis proyek. Jurnal Pendidikan Vokasi UNESA, 3(01), 247005.

Riduwan. (2012). Skala pengukuran variabel-variabel penelitian. Bandung: Alfabeta.

Sugihartono. (2007). Psikologi pendidikan. Yogyakarta: UNY Press.

Zancul, E. de S., Sousa-Zomer, T. T., \& Cauchick-Miguel, P. A. (2017). Project-based learning approach: Improvements of an undergraduate course in new product development. Producao, 27(Specialissue), 1-14. Download from https://doi.org/10. 1590/0103-6513.225216. 